\title{
Evaluation of Resistance to Asiatic Citrus Canker among Selections of Pêra Sweet Orange (Citrus sinensis)
}

Aline M. O. Gonçalves-Zuliani, Danielle S. Y. Nanami, and Bruna R. Barbieri, Núcleo de Pesquisa em Biotecnologia Aplicada, and, Terezinha A. Guedes, Departamento de Estatística, Universidade Estadual de Maringá, 87020-900, Maringá, Paraná, Brazil; Carlos A. Zanutto, Núcleo de Pesquisa em Biotecnologia Aplicada, Universidade Estadual de Maringá; Clive H. Bock, United States Department of AgricultureAgricultural Research Service Southeastern Fruit \& Tree Nut Research Lab, Byron, GA 31008; and William M. C. Nunes, Núcleo de Pesquisa em Biotecnologia Aplicada, Universidade Estadual de Maringá

\begin{abstract}
Gonçalves-Zuliani, A. M. O., Nanami, D. S. Y., Barbieri, B. R., Guedes, T. A., Zanutto, Bock, C. H. and Nunes, W. M. C. 2016. Evaluation of resistance to Asiatic citrus canker among selections of Pêra sweet orange (Citrus sinensis). Plant Dis. 100:1994-2000.

Asiatic citrus canker (ACC, caused by the bacterium Xanthomonas citri subsp. citri) is a destructive disease of citrus in Brazil and in several other citrus-producing countries. ACC management is problematic, and bactericides such as copper can be reasonably efficacious but do not completely control the disease. Furthermore, injury by citrus leaf miner (CLM) can exacerbate severity of ACC. Host resistance is the most desirable solution for management of ACC; however, evaluations of germplasm indicate that resistance is limited in many popular species and cultivars that are grown commercially. Limited evaluations have been made of sweet orange (Citrus sinensis) selections. We evaluated resistance of 25 Pêra sweet orange selections to $X$. citri subsp. citri by wound inoculation and measuring

lesion diameter under greenhouse conditions (wound inoculation indicates mesophyll resistance which will be valuable in areas where CLM exists). ACC severity was assessed on the same 25 selections at three locations in the field in Brazil, relying on natural inoculum and conditions to cause disease. In the greenhouse experiments, the selections EEL, Bianchi/CC, Ipiguá, Olimpia, IAC 2000/1, and Ovale Siracusa consistently had the smallest diameter lesions, indicating greatest resistance, although differences in lesion diameter were small. Results from the field experiments were less conclusive, although EEL and Ovale Siracusa were consistently numerically least affected by ACC. These results indicate selections of sweet orange that might be preferable to consider in canker-prone areas in Brazil and elsewhere.
\end{abstract}

The bacterium Xanthomonas citri subsp. citri (Schaad et al. 2006) causes Asiatic citrus canker (ACC) on several species of citrus. Severe epidemics of ACC result in economic losses to the citrus industry in regions of the world where the disease is endemic (Gottwald et al. 2002; Schubert et al. 2001), including Brazil (Behlau et al. 2010; Belasque and Behlau 2011).

$X$. citri subsp. citri is spread from active lesions of ACC, primarily in rain splash, which might be exacerbated by wind, or by transfer of infected material to new locations (Bock et al. 2010; Pruvost et al. 2002; Schubert et al. 2001). Symptoms of the disease develop on the leaves, stems, and fruit, initially as small necrotic lesions, usually surrounded by a yellow halo (Schubert et al. 2001). With increasing severity of symptoms on fruit, cracks may occur, serving as an entry for other pathogens and saprophytes, resulting in fruit quality and crop loss issues. Not only is there a direct yield loss but trade in fruit is also affected (Behlau et al. 2010; Gottwald et al. 2009; Laranjeira et al. 2005).

Susceptibility to $X$. citri subsp. citri can vary widely between citrus species and cultivars (Gottwald et al. 1993; Koizumi 1981; Leite and Mohan 1984; Stover et al. 2014; de Carvalho et al. 2015). Those with more prolonged or slow vegetative growth are more vulnerable to infection by the pathogen; resistance to $X$. citri subsp. citri within a cultivar is directly related to juvenility of the tissue (Gottwald and Graham 1992; Graham et al. 1992). According to Gottwald et al. (1993) and Vernière et al. (2003), citrus genotypes with greater frequency, size, and duration of vegetative growth are more susceptible to $X$. citri subsp.

\section{Corresponding author: W. M. C. Nunes; E-mail: wmcnunes@uem.br}

*The $\boldsymbol{e}$-Xtra logo stands for "electronic extra" and indicates that two supplementary figures and two supplementary tables are published online.

Accepted for publication 12 June 2016.

http://dx.doi.org/10.1094/PDIS-04-16-0502-RE

(C) 2016 The American Phytopathological Society citri in the field compared with those cultivars with less vigorous growth or those whose leaves mature more rapidly.

Susceptibility to $X$. citri subsp. citri can be based on development of the disease on leaf tissue, with evaluation of lesion diameter or leaf area cankered being important measures to verify the $X$. citri subsp. citri susceptibility (de Carvalho et al. 2015; Gottwald et al. 1993; Graham and Gottwald 1990; Nociti et al. 2006, Stover et al. 2014), although lesion count and bacterial population are also useful criteria (Egel et al. 1991; Stall et al. 1982; Viloria et al. 2004). Several methods have been used to challenge citrus genotypes with X. citri subsp. citri, and these include field screening relying on natural epidemic development (de Carvalho et al. 2015; Stover et al. 2014); greenhouse-based studies using artificial spray inoculations, including spray inoculation (Amaral et al. 2010); injection infiltration (Egel et al. 1991); wound inoculation (Belasque and Bergamin Filho 2006; Egel et al. 1991; Gottwald et al. 1993; Graham et al. 1990; Koizumi and Kuhara 1982); and pressure infiltration of foliage (Francis et al. 2010; Gottwald and Graham 1992; Viloria et al. 2004). Wound inoculation results in typical symptoms but bypasses any resistance mechanisms that might exist prior to pathogen entry (Favaro et al. 2014; Graham et al. 2004), yet still provides a method for comparing mesophyll susceptibility (Gottwald et al. 1993; Graham et al. 1990, 1992; Stall et al. 1982). It is important to emphasize that it ignores resistance mechanisms occurring prior to entry of the inoculum (Favaro et al. 2014). However, citrus canker occurs in many areas where the citrus leaf miner (CLM, Phyllocnistis citrella) causes foliar injury, and that injury exposes mesophyll and exacerbates severity of ACC (Christiano et al. 2007; Hall et al. 2010); thus, characterizing available mesophyll resistance in citrus germplasm is desirable.

Screening for resistance to ACC in a greenhouse environment is appealing because one can utilize smaller plants and use less space, which saves resources and allows the opportunity to screen more material compared with field or orchard-scale screenings (Viloria et al. 2004). However, the screening method used should be both accurate and reliable. Although resistance screening of genotypes to citrus canker in a greenhouse or laboratory has its advantages, it does not preclude the need for field studies (Belasque et al. 2008). Disease development in 
the field must ultimately be evaluated in relation to the host growth stage and other environmental and host factors that might influence disease expression. Nonetheless, greenhouse screening for resistance to citrus canker has been shown to be discerning (Amaral et al. 2010; Viloria et al. 2004).

Sweet orange (Citrus sinensis) is an important species of cultivated citrus in Brazil, and accounted for $93 \%$ (702,200 ha) of the harvested area of citrus in 2013 (FAO 2015; http://faostat3.fao.org/ home/E). However, there has been only limited screening of different selections of this species to ACC; thus, detailed, quantitative evaluations of sweet orange germplasm are warranted (Amaral et al. 2010; de Carvalho et al. 2015; Gottwald et al. 1993; Zubrzycki and Zubrzycki 1981). We evaluated resistance of 25 selections of Pêra sweet orange to $X$. citri subsp. citri in replicated experiments under greenhouse conditions using leaf wounding for inoculum introduction to the mesophyll of the foliage and, in three field experiments relying on natural inoculum over a period of 17 months, to identify the most resistant Pêra sweet orange selections.

\section{Materials and Methods}

Sources of sweet orange selections and $X$. citri subsp. citri. In total, 25 Pêra sweet orange selections were obtained from different sources: the germplasm collection at the Centro de Citricultura Silvio Moreira (Cordeirópolis, Sao Paolo, Brazil), Instituto Agronômico do Paraná (Londrina, Paraná, Brazil), and selections made by citrus growers in Paraná State (Table 1). These selections were chosen to provide a diversity of sweet orange germplasm that would be of interest in the region. The isolate of $X$. citri subsp. citri used to inoculate greenhouse-grown plants was $X$. citri subsp. citri 306, obtained from the Fundo de Defesa da Citricultura (Fundecitrus, Sao Paulo, Brazil) collection and stored at the Núcleo de Pesquisa em Biotecnologia Aplicada of Universidade Estadual de Maringá (Maringá, Paraná, Brazil). The bacterium was stored in a suspension of phosphate buffer $(0.075 \mathrm{M}, \mathrm{pH} 7.0)$ in a refrigerator.

Greenhouse experiment-plant and bacterial culture and inoculum preparation. The experiment was conducted in a greenhouse at the Núcleo de Pesquisa em Biotecnologia Aplicada installation $\left(23^{\circ} 23^{\prime} 57.8^{\prime \prime} \mathrm{S}, 51^{\circ} 57^{\prime} 5.3^{\prime \prime} \mathrm{W}, 500 \mathrm{~m}\right.$ in elevation) and repeated once. The first experimental run was conducted from November 2011 to January 2012 and the second run was conducted from April to June 2012.

The Pêra sweet orange selections were on Rangpur lime $(C$. limonia) rootstock and grown in composted pine bark and vermiculite in containers ( 15 by $35 \mathrm{~cm}, 4,000 \mathrm{~cm}^{3}$; Wolff Klabin MEC Prec) at the Viveiro de Mudas Pratinha nursery (Atalaia, Paraná, Brazil). The nursery designated the selections 201 to 225 , an abbreviation used in this study (Table 1). The potted plants were maintained in a greenhouse with a cycle of approximately $12 \mathrm{~h} /$ day and $12 \mathrm{~h} /$ night. During early November 2011 to January 2012, the temperature ranged from 23 to $35^{\circ} \mathrm{C}$. From April to June 2012, the temperature ranged from 13 to $25^{\circ} \mathrm{C}$.

The young potted trees received standard nursery management, including periodic fertilization with $\mathrm{N}, \mathrm{P}$, and $\mathrm{K}$, and pesticide applications to control rust mite, scab and melanosis (Mattos et al. 2005). Five replicate plants per selection were prepared. Approximately 50 days before inoculation, the plants were pruned in order to obtain a homogeneous fresh flush of immature leaves, ensuring that a majority were 75 to $100 \%$ fully expanded. According to Viloria et al. (2004), this stage of foliar expansion is ideal for challenging citrus with $X$. citri subsp. citri.

Fresh X. citri subsp. citri cultures were prepared by transferring the storage suspension by streaking onto fresh nutrient agar ( $3 \mathrm{~g}$ of beef extract, $5 \mathrm{~g}$ of peptone, $5 \mathrm{~g}$ of sodium chloride, and $15 \mathrm{~g}$ of agar per liter of distilled water) in petri plates which were incubated for approximately $48 \mathrm{~h}$ at $28^{\circ} \mathrm{C}$. An inoculum suspension was prepared from the cultures in phosphate buffer $(0.075 \mathrm{M}, \mathrm{pH} 7.0)$, adjusted to $10^{8} \mathrm{CFU} / \mathrm{ml}$ (Belasque and Bergamin Filho 2006) with the aid of a spectrophotometer at $600 \mathrm{~nm}$. The suspension was used for inoculation immediately after preparation.

Greenhouse experiment-inoculation and assessment of symptoms. The inoculation method was as follows. Uniform subepidermal leaf wounding was inflicted using a hypodermic needle ( 0.55 by $0.20 \mathrm{~mm}$ ), using only the tip of the needle to ensure uniform wounding by perforating the epidermis only on the abaxial surface. Each leaf was wounded with eight subepidermal perforations, with four each to the left and right of the midrib, and equidistantly distributed. Immediately after wounding, the leaf was immersed in the suspension of $X$. citri subsp. citri. Four leaves were inoculated per plant (total of 32 lesions/plant), with a total of five plants per selection. Prior to inoculation, the plants were placed on the greenhouse bench following a completely randomized experimental design when placing the five replicate plants of each of the 25 selections. During the first $24 \mathrm{~h}$ after inoculation, high humidity and constant surface wetness were maintained. The potted trees were watered and the ground surrounding the pots was kept wet by soaking the greenhouse floor for $5 \mathrm{~min}$ three times during the 24-h period. Surface wetness was observed on the leaves over the $24-h$ period. Careful attention was paid to avoid applying moisture to the inoculated leaves. At each assessment, four lesions were arbitrarily selected from the lesion population on each plant. Thus, the four lesions on each leaf were not necessarily the same, or from the same leaf, on each assessment date.

Diameter of lesions was measured in the first experiment at 18,24 , $33,39,46,61,68$, and 76 days after inoculation (DAI). In the second experiment, the measurements were taken at 22, 32, 39, 46, 54, 58, 69, and 76 DAI. A micrometer (Mitutoyo Corporation) was used to measure the diameter of the lesions (in millimeters).

Lesion diameter was measured along the leaf axis. For purposes of standardization, lesion diameter was measured only on the abaxial surface of the leaves. Only the necrotic area of the lesion was measured. The necrotic area of the lesion is sharply defined (although also of potential interest, the chlorotic halo was not measured due to the degree of subjectivity in determining where the chlorosis starts or ends, which might introduce error into measurements).

Field experiments - plant cultivation and disease assessment. The same 25 selections of Pêra sweet orange were included in three

Table 1. Pêra sweet orange selections screened for resistance to Xanthomonas citri subsp. citri by wound inoculation in two greenhouse experiments and three field experiments

\begin{tabular}{|c|c|c|}
\hline Code $^{a}$ & Selection $^{\mathbf{b}}$ & Origin $^{c}$ \\
\hline 201 & Pêra EEL & CCSM \\
\hline 202 & Pêra Bianchi/CC & CCSM \\
\hline 203 & Pêra IAC & CCSM \\
\hline 204 & Pêra Ipigua & CCSM \\
\hline 205 & Pêra Olimpia & CCSM \\
\hline 206 & Pêra IAC 2000/1 & CCSM \\
\hline 207 & Pêra Ovale Siracusa & CCSM \\
\hline 208 & Pêra Ovale & CCSM \\
\hline 209 & Pêra Dibbern & CCSM \\
\hline 210 & Pêra Coroada & CCSM \\
\hline 211 & Pêra Roberto Gulo & CCSM \\
\hline 212 & Pêra Pêrão & CCSM \\
\hline 213 & Pêra Pirangi & CCSM \\
\hline 214 & Pêra Ovo & CCSM \\
\hline 215 & Pêra Fumio & VMP \\
\hline 216 & Pêra IAC 2000/2 & CCSM \\
\hline 217 & Pêra - C & VMP \\
\hline 218 & Pêra, M 6 & VMP \\
\hline 219 & Pêra, M 5 & VMP \\
\hline 220 & Pêra Roque & VMP \\
\hline 221 & Pêra Arapongas & VMP \\
\hline 222 & Pêra, D 6 & IAPAR \\
\hline 223 & Pêra 58 & IAPAR \\
\hline 224 & Pêra Bianchi /IP & IAPAR \\
\hline 225 & Pêra 59 & IAPAR \\
\hline
\end{tabular}

a Selection code (provided by the nursery).

b Pêra sweet orange selections name.

c CCSM = Centro de Citricultura Silvio Moreira, Cordeirópolis, SP; VMP = Viveiro de Mudas Pratinha, Paranavaí, PR; and IAPAR = Instituto Agronômico do Paraná, Londrina, PR, Brazil. 
field demonstration blocks. The young budded trees were planted in 2008 after grafting on Rangpur lime rootstock, with a spacing of 2.5 by $6.0 \mathrm{~m}$. There were 30 trees planted per selection at three locations in Paraná State, Brazil: Congonhinhas $\left(23^{\circ} 29^{\prime} \mathrm{S}, 50^{\circ} 29^{\prime} \mathrm{W}\right.$, and $757 \mathrm{~m}$ in elevation), Cornélio Procópio $\left(23^{\circ} 05^{\prime} \mathrm{S}, 50^{\circ} 38^{\prime} \mathrm{W}\right.$, and $360 \mathrm{~m}$ in elevation), and Paranavai $\left(23^{\circ} 1^{\prime} \mathrm{S}, 50^{\circ} 41^{\prime} \mathrm{W}\right.$, and $467 \mathrm{~m}$ in elevation).

Precipitation data over the period of disease assessment was obtained for Iguatemi Experimental Farm, University of Maringá, Maringá, Paraná State $\left(23^{\circ} 25^{\prime} \mathrm{S}, 51^{\circ} 57^{\prime} \mathrm{W}\right.$, and $550 \mathrm{~m}$ in elevation) and monthly totals were calculated (Supplementary Fig. S1A). Maringa is 160, 144, and $72 \mathrm{~km}$ from Congonhinhas, Cornélio Procópio, and Paranavai, respectively, but the locations have similar climates (all three locations fall in the Cfa category of the Köppen climate classification system, which is characterized by a humid, moderate climate without dry seasons and with the average temperature of the hottest month $>22^{\circ} \mathrm{C}$ ).

Because these demonstration plots had no formal design, analysis was precluded. The plants received standard management for commercial orange orchards in Brazil (Mattos et al. 2005), including cupric products for ACC (four applications from September to January). Sprays alternated between Recop (copper oxychloride at $3.6 \mathrm{~kg}$ per 2,000 liters; Atar Agricultural Defensive) and Kocide (copper hydroxide at $2.5 \mathrm{~kg}$ per 2,000 liters; Dupont). Natural infection was relied on for development of ACC, with inoculum coming from surrounding orchards ('Valencia' and 'Folha Murcha') at each location.

Severity of disease on foliage was assessed quarterly in 2010, 2011, and 2012 at Congonhinhas and Cornelio (19 October 2010, 7 February 2011, 11 May 2011, 24 August 2011, 6 December 2011, and 7 March 2012) and Paranavaí (26 October 2010, 8 February 2011, 12 May 2011, 24 August 2011, 7 December 2011, and 8 March 2012). Severity was assessed on 10 plants of each selection; four branches per plant were arbitrarily selected. The severity (percent area diseased) was visually estimated by four experienced evaluators on each leaf using a reference standard area diagram set to aid accuracy (Belasque et al. 2005). Only data for cankered leaves are described.

Data analysis. Data were analyzed using SAS (V9.3; SAS Institute). For the greenhouse ACC lesion diameter data, area under the disease progress curve (AUDPC) for lesion diameter for each plant of each selection was calculated by trapezoidal integration (Campbell and Madden 1990). Because the lesions selected for diameter measurements were not the same ones in each assessment, the diameters were averaged per plant prior to calculating AUDPC for each plant. A general linear model was used to analyze the AUDPC with main effects of selection. Prior to analysis, data were inspected for heterogeneity of variance and residual distribution and were deemed normally distributed and amenable to parametric analysis. Main effect means for selection were compared using Tukey's honestly significant difference $(\alpha=0.05)$. For all analyses, the 95\% confidence intervals for the means were calculated.

Field data were not amenable to statistical analysis but are presented as means. Associations in severity among selections from the two greenhouse experiments and from the three field experiments were explored using Pearson's product moment correlation analysis.

\section{Results}

In both greenhouse assays, all selections showed susceptibility to ACC. The observed symptoms were characteristic of the disease, and it was possible to distinguish differences among the selections in relation to lesion diameter (Fig. 1). In the first trial, symptoms were observed 12 DAI with the pathogen whereas, in the second trial, symptoms were first observed 10 DAI. Furthermore, the lesions developed continuously during the evaluation period of both experiments (76 days). There was some variation for lesion diameter on specific selections with time because different lesions were measured on different dates but, overall, there was an increase in diameter over the assessment period.

There were significant effects of the sweet orange selection on the diameter of lesions. In the first experiment $(F=13.69, P<0.0001)$, the mean diameters of the lesions on the different selections ranged from 1.37 to $1.73 \mathrm{~mm}$ at $18 \mathrm{DAI}$ to 1.66 to $2.43 \mathrm{~mm}$ at $76 \mathrm{DAI}$ (Fig. 2; Supplementary Table S1) whereas, in the second experiment $(F=208.34, P<0.0001)$, the mean diameters of the lesions on the different selections ranged from 1.65 to $2.11 \mathrm{~mm}$ at 22 DAI to 2.70 to $3.89 \mathrm{~mm}$ at 76 DAI (Fig. 2; Supplementary Table S2). Lesion sizes measured tended to be larger in experiment 2 compared with experiment 1 . There were some differences among selection ranking for lesion size at each assessment date.

In the first greenhouse experiment, the Pêra sweet orange selections with the smallest canker lesions (Tukey groups $i$ and $j$; Fig. 3A) were
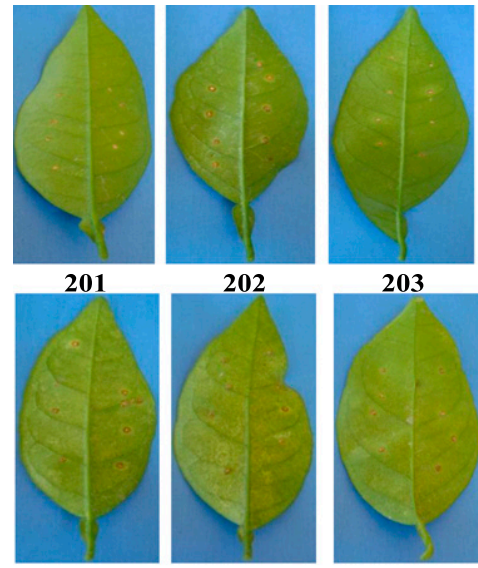

210

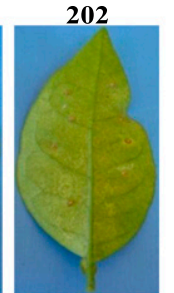

211

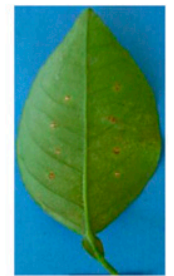

219

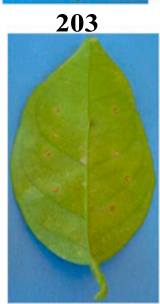

212

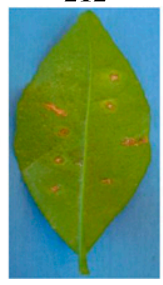

220

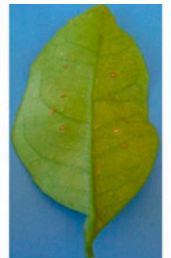

204

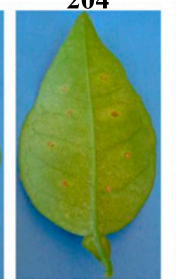

213

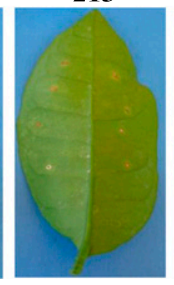

221

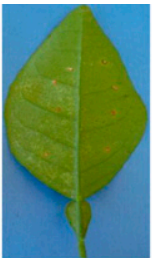

205

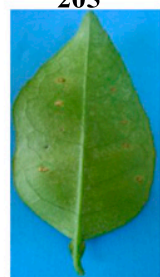

214

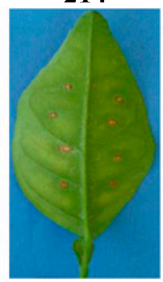

222
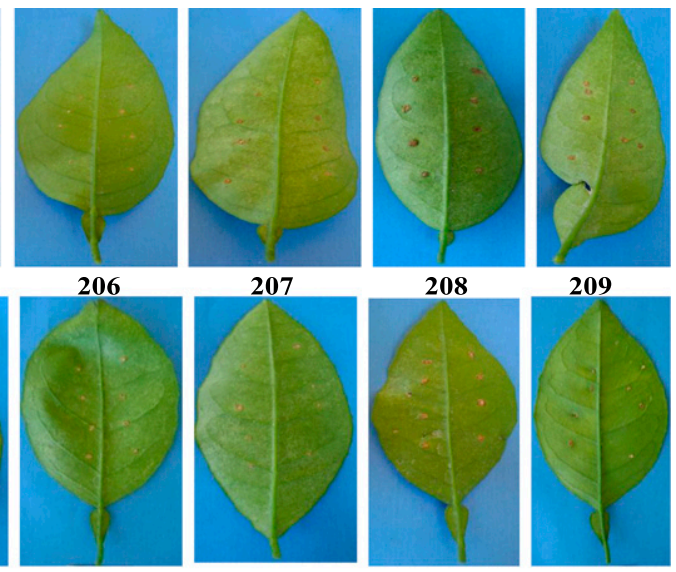

215

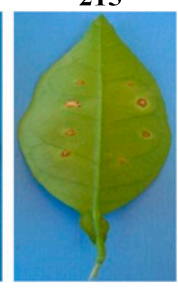

223

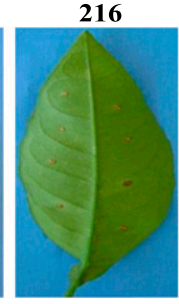

224

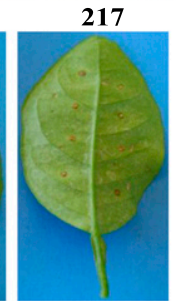

225

Fig. 1. Sample leaves of the 25 Pêra sweet orange selections 76 days after inoculation and showing the typical range in size of lesions of citrus canker caused by Xanthomonas citri subsp. citri. 
EEL (201), Bianchi/CC (202), Ipiguá (204), Olimia (205), IAC 2000/1 (206), Ovale Siracusa (207), Coroada (210), Roberto Gulo (211), Pêrao (212), Ovo (214), IAC 2000/2 (216), and M-5 (219). The selections with the largest diameter lesions (Tukey group a) were Ovale (208), Fumio (215), C (217), Roque (220), Aropongas (221), D-6 (222), 58 (223), Bianchi/IP (224), and 59 (225). In the second greenhouse experiment, the Pêra sweet orange selections with the smallest canker lesions (Tukey groups h, I, and j; Fig. 3B) were EEL (201), Bianchi/CC (202), IAC (203), Ipiguá (204), Olimia (205), IAC 2000/1 (206), Ovale Siracusa (207), and Dibbern (209). The selections with the largest diameter lesions (Tukey group a) were M-5 (219), Roque (220), D-6 (222), 58 (223), Bianchi/IP (224), and 59 (225).

A few selections were not entirely consistent between experiments. These included IAC (203), IAC 2000/2 (216), C (217), and M-5 (219). The reason for this is not known but might be due to the method or subtle differences in leaf age at inoculation. The remaining selections were intermediate in lesion diameter.

With regard to the field experiments, the mean severity of citrus canker for each site and assessment date showed that severity was consistently numerically greatest at Paranavai (overall mean canker severity $1.29 \%$ leaf area), while severity was consistently low at both Congonhinhas (overall mean canker severity $0.19 \%$ leaf area) and Cornélio Procópio (overall mean canker severity $0.36 \%$ leaf area) (Fig. 4A to C). In all three field experiments, the severity of ACC varied with selection and assessment date during the 17 months that the plants were monitored (Supplementary Figs. S1B and S2), which is not surprising because epidemics of ACC are known to change in intensity throughout the year in relation to rainfall and new growth (Gottwald et al. 1992).

There was a strong association between AUDPC for lesion diameter for the different selections from the two greenhouse experiment (Table 2). However, the field experiments did not show as much association among selections for ACC severity with each other or with AUDPC from the greenhouse experiments. Only at Paranavai (the location with the most severe ACC of the three field experiments) was mean severity on the foliage associated with AUDPC from greenhouse experiment 2 and with severity of ACC at Congonhinhas. AUDPC in greenhouse experiment 2 was also associated with severity of ACC at Cornélio Procópio. There was a weak association between AUDPC among selections from greenhouse experiment 2 and the severity of ACC at Paranavai $(P=0.08)$.

\section{Discussion}

In the greenhouse experiments, all selections of Pêra sweet orange were susceptible to ACC and produced symptoms typical of the disease (Belasque et al. 2008; Gottwald et al. 1993; Schubert et al. 2001). Symptoms developed 10 to 12 DAI, which is in agreement with results of other studies (Belasque et al. 2008; Nociti et al. 2006; Viloria et al. 2004). It has been established that, although sweet orange is susceptible, a range in susceptibility does appear to exist among selections (Amaral et al. 2010; de Carvalho et al. 2015). We confirmed a range in susceptibility among the different selections tested in the experiments in this study and, although the ranking was not entirely consistent in the greenhouse experiments, there was a strong correlation between them.
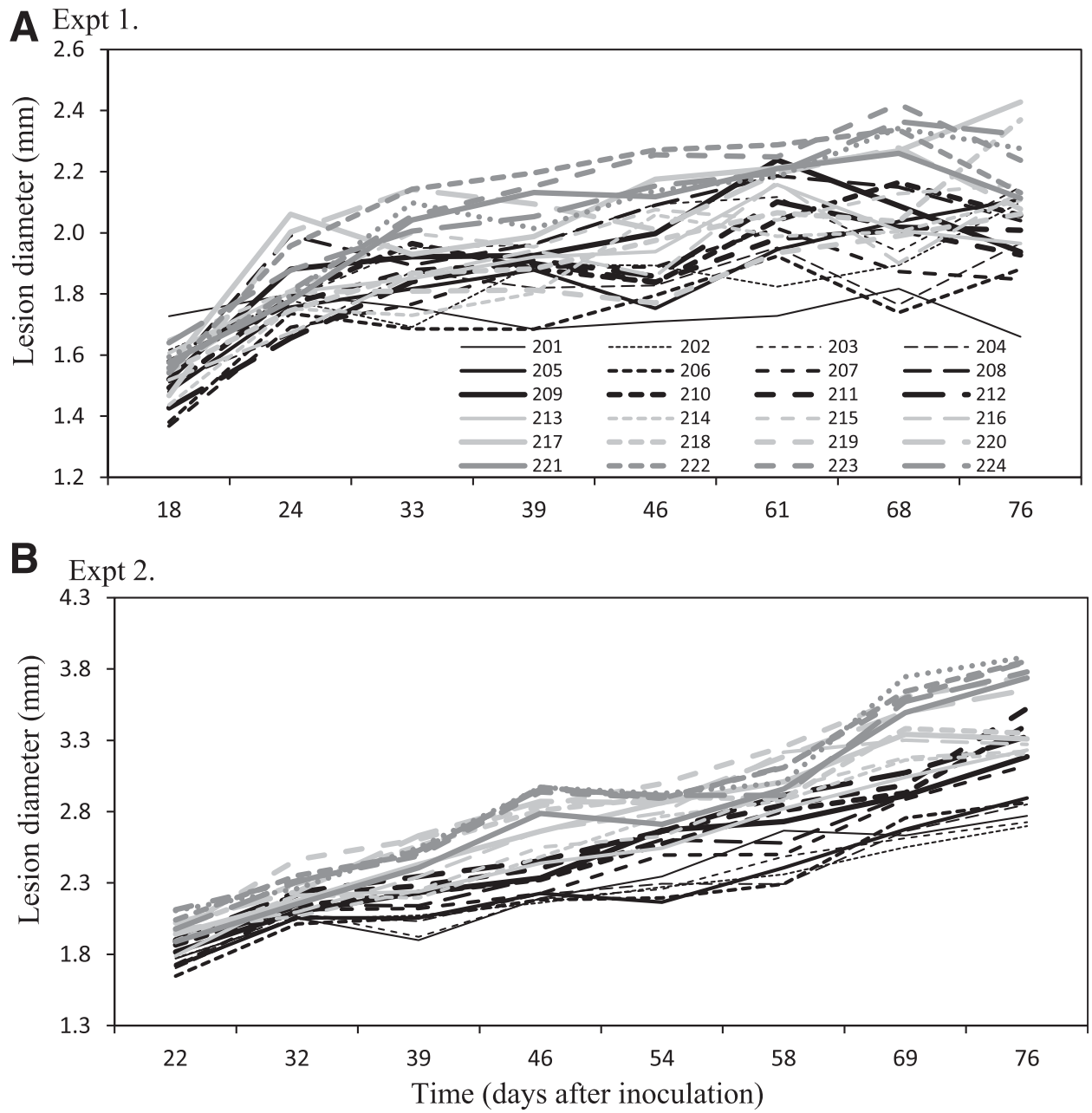

Fig. 2. Spaghetti chart showing mean lesion diameters (in millimeters) of citrus canker caused by Xanthomonas citri subsp. citri on 25 different Pêra sweet orange selections in greenhouse experiment 1 (A) and 2 (B) at different times after wound inoculation. 
The selections that demonstrated resistance in both greenhouse experiments were EEL (201), Bianchi/CC (202), Ipiguá (204), Olimpia (205), IAC 2000/1 (206), and Ovale Siracusa (207). The most susceptible selections included Roque (220), D-6 (222), 58 (223), Bianchi/IP (224), and 59 (225). In another study, Amaral et al. (2010) also found EEL, Olimpia, Ovale Siracusa, and Ipiguá to be resistant or moderately resistant compared with other sweet orange selections when using sprayed inoculum. de Carvalho et al. (2015) found a range in susceptibility among sweet orange selections, although only a few selections were common with the ones described here. The remaining selections of sweet orange in the greenhouse experiment showed inconsistent levels of disease susceptibility between runs or were of intermediate disposition in regard to lesion diameter. Those that were most resistant to $X$. citri subsp. citri in these two runs would appear to have some potential for commercial production to reduce ACC severity in canker-prone areas alongside an integrated management plan. They do not provide sufficient resistance to be of obvious value to a breeding program as a source of canker resistance.

The results from the field experiments were less consistent than the greenhouse experiments. Low severity of ACC over the duration of the three experiments at two locations (Congonhinhas and Cornélio Procópio) might have led to escapes or to inconsistent, uneven canker developing in the canopy of trees in limited zones of the orchard. The three field experiments received standard application of cupric products to control ACC, and would have contributed to the consistently low severity of ACC. Nonetheless, there was some agreement between the resistance ratings among the field experiments, and correlation analysis showed association between field experiments and greenhouse experiments (particularly between the field experiment at Paranavai and greenhouse experiment 2).

The greenhouse tests relied on wound inoculation, which bypasses resistance mechanisms that might occur at the cuticular or epidermal surface layer, including waxes and size and density of stomata
(Favaro et al. 2014; Gottwald et al. 1993; Graham et al. 1992; Stall et al. 1982; Wang et al. 2011). Indeed, stomata might play an active role in defense against $X$. citri subsp. citri, as has been shown in other plant-pathogenic bacteria (Melotto et al. 2008). Thus, any resistance expressed in the greenhouse tests is related to expression of mesophyll resistance (Graham et al. 1992; Stall et al. 1982). However, an advantage of the wound inoculation method is that it standardizes comparisons among genotypes in relation to development stages regarding surface or epidermal characteristics such as stomatal development and cuticular wax formation (Graham et al. 1992; Stall et al. 1982), and wounding followed by inoculation has been shown to provide a more discerning measure of genotype resistance compared with injection infiltration using a hypodermic needle (Egel et al. 1991). Indeed, wound inoculation has been a widely used method for screening citrus germplasm (Belasque et al. 2008; Gottwald et al. 1993; Koizumi and Kuhara 1982; Leite and Mohan 1984; Nociti et al. 2006), although it can result in more rapid and greater disease incidence and severity compared with spray inoculation or relying on natural inoculum, and cause disease on material that might otherwise not become infected (Vernière et al. 2003). Indeed, Gottwald et al. (1993) already demonstrated that wounding can bypass field tolerance in mandarin orange. However, in that study, they also showed that there were differences among selections of citrus after wounding (trifoliate orange fruit were particularly susceptible). Both methods (lesion diameter and severity on foliage) have been assessed previously using wounding or relying on natural inoculum to assess genotype response to disease (de Carvalho et al. 2015; Egel et al. 1991; Gottwald et al. 1993; Graham et al. 1990; Nociti et al. 2006; Stover et al. 2014).

It is worthy to note that wounding is an important consideration where CLM occurs and, on this basis, can be considered a valid screening procedure. CLM occurs in Brazil and injury by the pest exposes mesophyll directly to inoculum of $X$. citri subsp. citri (Christiano et al. 2007; Hall et al. 2010). For this reason, those cultivars

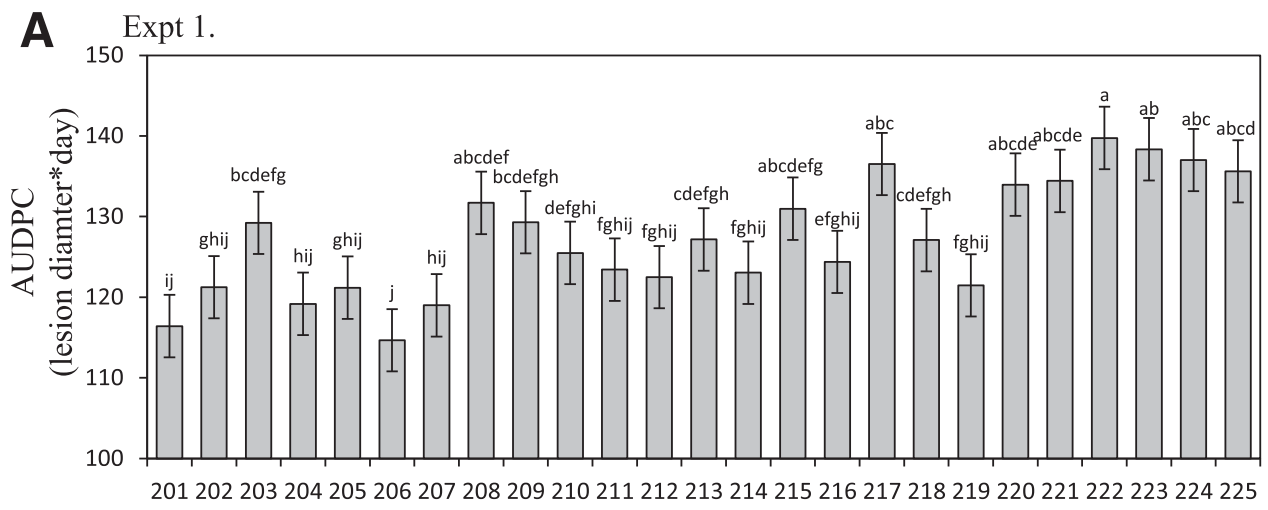

B

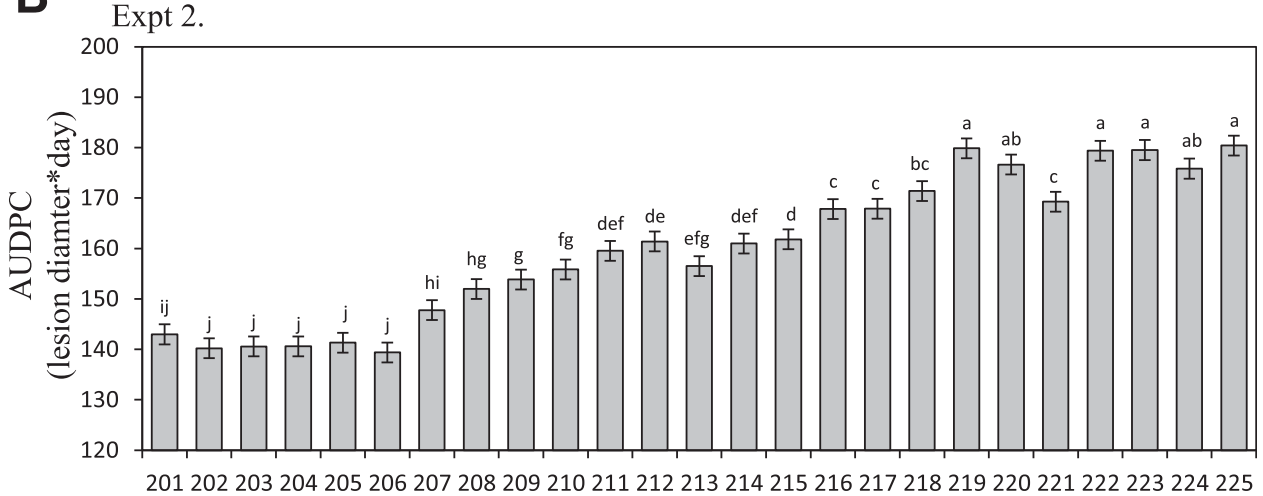

Selection

Fig. 3. Effect of selection showing mean (Ismean) of the area under the disease progress curve (AUDPC) for lesion diameter of citrus canker caused by Xanthomonas citri subsp. citri on 25 selections of Pêra sweet orange wound inoculated in greenhouse experiment 1 (A) and 2 (B). Means with the same letter are not significantly different based on Tukey's honestly significant difference test $(\alpha=0.05)$. 
that show greater mesophyll resistance to $X$. citri subsp. citri will be more desirable, although effective management of CLM will still be required.

Lesions of ACC continued to expand in most selections up to at least 60 DAI (Egel et al. 1991; Graham et al. 1990; Nociti et al. 2006). We measured lesions to 76 DAI, and there was still some evidence of lesion expansion, particularly in greenhouse experiment 2. However, we observed that, within a particular selection, lesion diameter did not always increase, which might be attributable to the random selection of lesions that were measured from the population of lesions on each selection (i.e., measurements were not repeated on the same lesions for each evaluation).

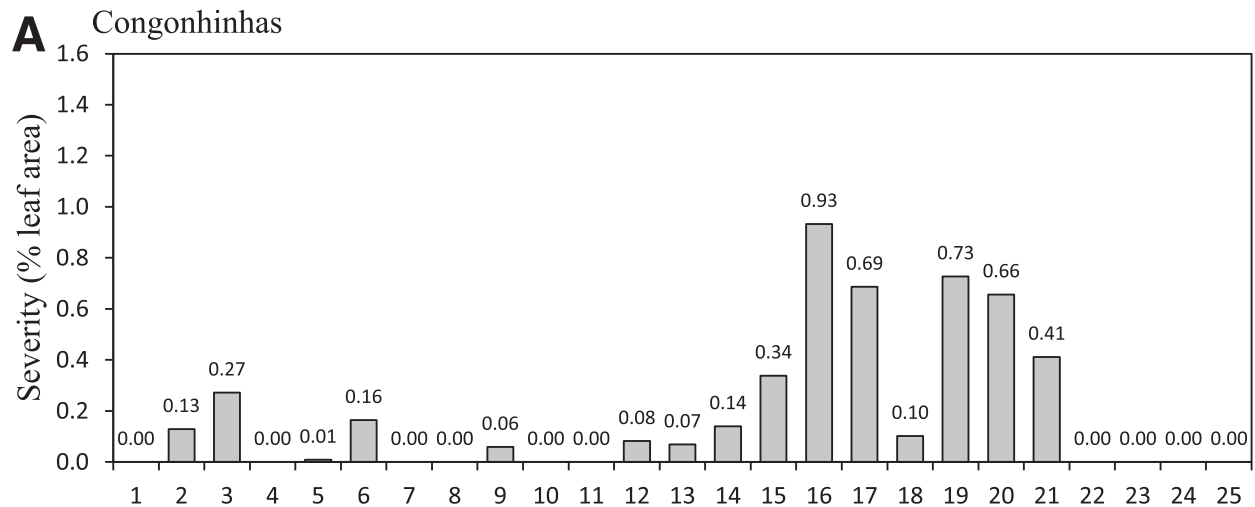

B

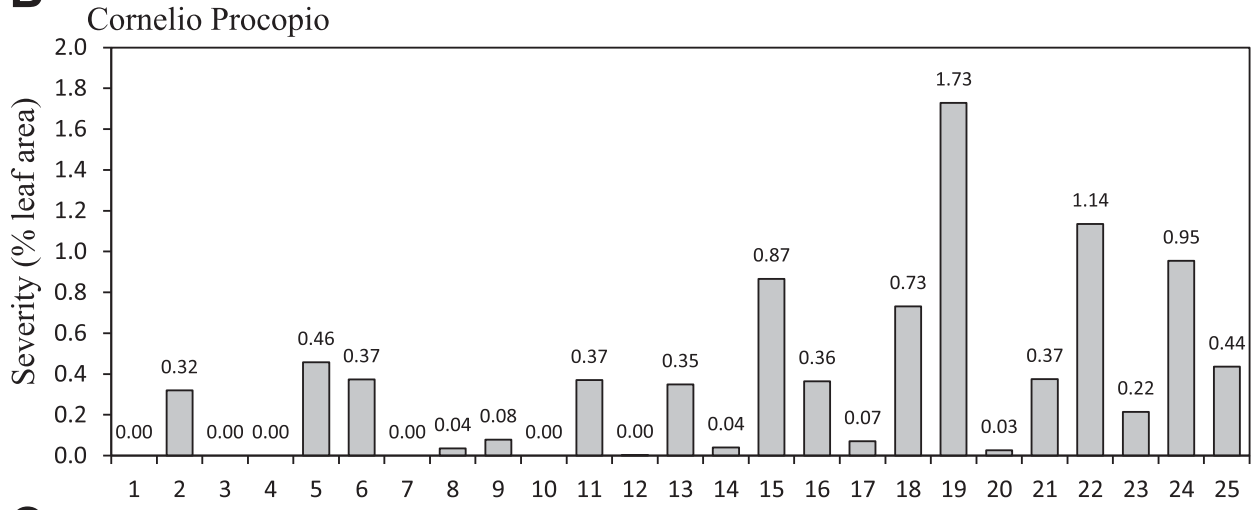

C

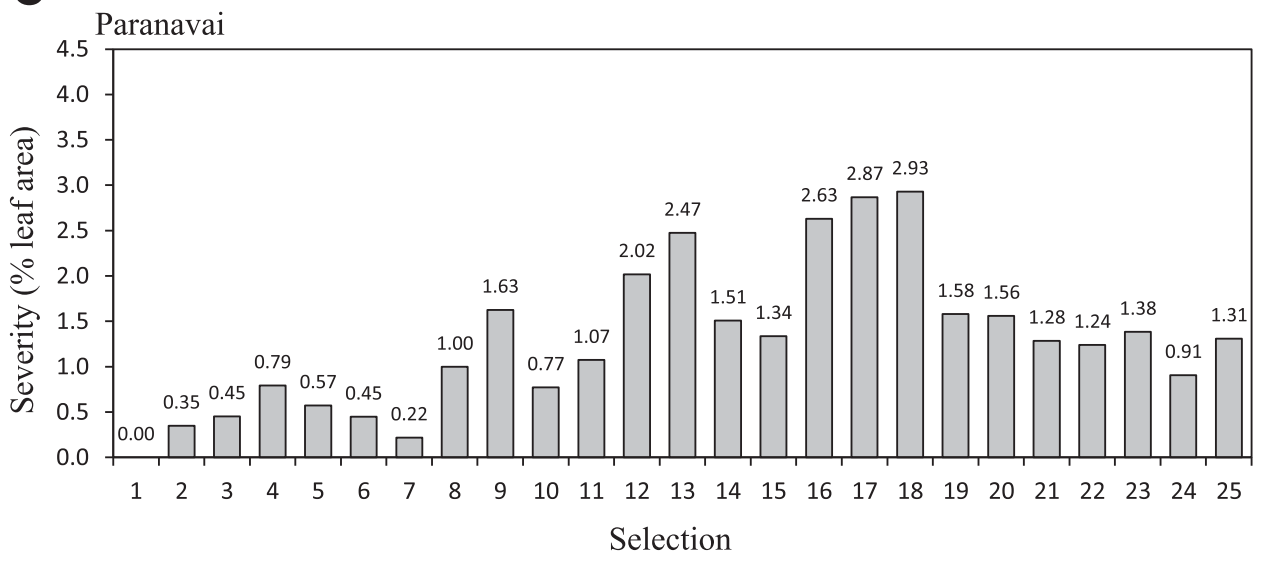

Fig. 4. Severity of citrus canker (percent leaf area) caused by Xanthomonas citri subsp. citri on leaves of 25 different Pêra sweet orange selections from Congonhinhas (A), Cornelio Procopio (B), and Paranavai (C) in Parana State, Brazil.

Table 2. Pearson's correlation analysis (and $P$ values) for severity of symptoms of citrus canker caused by Xanthomonas citri subsp. citri on 25 selections of sweet orange among different experiments ${ }^{\mathrm{a}}$

\begin{tabular}{|c|c|c|c|c|}
\hline & GH1 AUDPC & GH2 AUDPC & Congonhinhas & Cornélio Procópio \\
\hline GH2 AUDPC & $0.705(<0.0001)$ & $\ldots$ & $\ldots$ & $\ldots$ \\
\hline Congonhinhas & $0.097(0.6)$ & $0.332(0.1)$ & $\ldots$ & $\ldots$ \\
\hline Cornélio Procópio & $0.186(0.4)$ & $0.511(0.009)$ & $0.214(0.3)$ & $\ldots$ \\
\hline Paranavai & $0.359(0.08)$ & $0.565(0.003)$ & $0.483(0.02)$ & $0.159(0.5)$ \\
\hline
\end{tabular}

\footnotetext{
${ }^{a}$ Values in bold indicates that the association between the variables was significant $(P \leq 0.05) ; r$ values are indicated, followed by the $P$ value in parentheses. In two experiments, the plants were wound inoculated and the diameter of lesions was measured; in three field experiments, plants developed disease due to naturally occurring inoculum, and severity (percent area) was estimated on the leaves. GH = greenhouse experiment 1 or 2; AUDPC = area under the disease progress curve; and Congonhinhas, Cornélio Procópio, and Paranavai = field experiments.
} 
Sweet orange (C. sinensis) is thought to have originated through hybridization in northern Asia (Hodgson 1967; Morton 1987). The different selections are considered to be near-isogenic mutants due to clonal propagation from selected types. Furthermore, Pêra is considered to be the same as Lamb Summer (Hodgson 1967), which is believed to have been selected approximately 150 years ago. Despite the relatively recent development of Pêra selections, there appear to be detectable differences in susceptibility both in mesophyll resistance, as demonstrated in this study, and due to spray inoculation or field inoculum, as demonstrated previously (Amaral et al. 2010; de Carvalho et al. 2015).

The results suggest that the Pêra sweet orange selections EEL, IAC 2000/1, Bianchi/CC, and IAC had the highest and most consistent resistance to ACC; although the differences observed in this study were small, the least susceptible cultivars may provide some limited commercial advantages in canker-prone areas (particularly as part of an integrated canker-management program). However, further work is needed. This resistance is likely due to characteristics in the mesophyll. ACC resistance is the best long-term solution for the management of citrus canker, and these selections might be useful resources in canker-prone areas.

\section{Acknowledgments}

We thank The National Council for Scientific and Technological Development for financial aid provided and granted to W. M. C. Nunes, Coordination of Improvement of Higher Education Personnel for financial assistance granted to A. M. O. Gonçalves-Zuliani and D. S. Y. Nanami through a scholarship, J. A. Remolli for substantial assistance in plant maintenance and data collection, and J. Belasque, Jr. for help with the evaluation method of greenhouse plants.

\section{Literature Cited}

Amaral, A. M., Carvalho, S. A., Silva, L. F. C., and Machado, M. A. 2010. Reaction of genotypes of citrus species and varieties to Xanthomonas citri subsp. citri under greenhouse conditions. J. Plant Pathol. 92:519-524.

Behlau, F., Belasque, J., Jr., Graham, J., and Leite, R., Jr. 2010. Effect of frequency of copper application on control of citrus canker and the yield of young bearing sweet orange trees. Crop Prot. 29:300-305.

Belasque, J., Jr., Bassanezi, R. B., Spósito, M. B., Ribeiro, L. M., Jesus, W. C., Jr., and Amorim, L. 2005. Escalas diagramáticas para avaliação da severidade do cancro cítrico. Fitopatol. Bras. 30:387-393.

Belasque, J., Jr., and Behlau, F. 2011. Current status of citrus canker control in São Paulo State, Brazil: A new chapter in a 50-year book? Pages 14-16 in: Proc. Int. Workshop Xanthomonas citri/Citrus Canker. Session 1-Citrus Canker Current Status and Economical Importance. Online publication. Ribeirão Preto, Brazil. http://lgb.rc.unesp.br/wxc/

Belasque, J., Jr., and Bergamin Filho, A. 2006. Estratégias de controle do cancro cítrico. Summa Phytopathol. 32:143-148.

Belasque, J., Jr., Jaciani, F. J., Marin, D. R., and Barbosa, J. C. 2008. Tamanho da amostra para quantificação do diâmetro de lesões de cancro cítrico. Trop. Plant Pathol. 33:317-322.

Bock, C. H., Graham, J. H., Gottwald, T. R., Cook, A. Z., and Parker, P. E. 2010. Wind speed and wind-associated leaf injury affect severity of citrus canker on Swingle citrumelo. Eur. J. Plant Pathol. 128:21-38.

Campbell, C. L., and Madden, L. V. 1990. Introduction to Plant Disease Epidemiology. Wiley, New York

de Carvalho, S. A., Nunes, W. M. C., Belasque, J., Jr., Machado, M. A., CroceFilho, J., Bock, C. H., and Abdo, Z. 2015. Comparison of resistance to Asiatic citrus canker among different genotypes of Citrus in a long-term canker-resistance field screening experiment in Brazil. Plant Dis. 99:207-218.

Christiano, R. S. C., Dalla Pria, M., Jesus, W. C., Jr., Parra, J. R. P., Amorim, L., and Bergamin Filho, A. 2007. Effect of citrus leaf-miner damage, mechanical damage and inoculum concentration on severity of symptoms of Asiatic citrus canker in Tahiti lime. Crop Prot. 26:59-65.

Egel, D. S., Graham, J. H., and Stall, R. E. 1991. Genomic relatedness of Xanthomonas campestris strains causing diseases of citrus. Appl. Environ. Microbiol. 57:2724-2730.

FAO. 2015. Online publication. Food and Agriculture Organization of the United Nations, Statistics Division. http://faostat3.fao.org/home/E

Favaro, M. A., Micheloud, N. G., Roeschlin, R. A., Chiesa, M. A., Castagnaro, A. P., Vojnov, A. A., Gmitter, F. G., Jr., Gadea, J., Rista, L. M., Gariglio, N. F., and Marano, M. R. 2014. Surface barriers of mandarin 'Okitsu' leaves make a major contribution to canker disease resistance. Phytopathology 104:970-976.

Francis, M. I., Pena, A., and Graham, J. H. 2010. Detached leaf inoculation of germplasm for rapid screening of resistance to citrus canker and citrus bacterial spot. Eur. J. Plant Pathol. 127:571-578.

Gottwald, T., Graham, J., Bock, C. H., Bonn, G., Civerolo, E., Irey, M., Leite, R., Lopez, M., McCollum, G., Parker, P., Ramallo, J., Riley, T., Schubert, T., Stein, B., and Taylor, E. 2009. The epidemiological significance of postpackinghouse survival of Xanthomonas citri ssp. citri for dissemination of Asiatic citrus canker via infected fruit. Crop Prot. 28:508-524.
Gottwald, T. R., and Graham, J. H. 1992. A device for precise and nondisruptive stomatal inoculation of leaf tissue with bacterial pathogens. Phytopathology 82 : 930-935.

Gottwald, T. R., Graham, J. H., Civerolo, E. L., Barrett, H. C., and Hearn, C. J. 1993. Differential host range of Citrus and Citrus relatives to citrus canker and citrus bacterial spot determined by leaf mesophyll susceptibility. Plant Dis. 77:1004-1009.

Gottwald, T. R., Graham, J. H., and Schubert, T. S. 2002. Citrus canker: The pathogen and its impact. Online publication. Plant Health Prog. doi:10.1094/ PHP-2002-0812-01-RV

Gottwald, T. R., Reynolds, K. M., Campbell, C. L., and Timmer, W. L. 1992. Spatial and spatiotemporal autocorrelation analysis of citrus canker epidemics in citrus nurseries and groves in Argentina. Phytopathology 82:843-851.

Graham, J. H., and Gottwald, T. R. 1990. Variation in aggressiveness of Xanthomonas campestris pv. citrumelo associated with citrus bacterial spot in Florida citrus nurseries. Phytopathology 80:190-196.

Graham, J. H., Gottwald, T. R., Cubero, J., and Achor, D. S. 2004. Xanthomonas axonopodis pv. citri: Factors affecting successful eradication of citrus canker. Mol. Plant Pathol. 5:1-15.

Graham, J. H., Gottwald, T. R., and Fardelmann, D. 1990. Cultivar-specific interactions for strains of Xanthomonas campestris from Florida that cause citrus canker and citrus bacterial spot. Plant Dis. 74:753-756.

Graham, J. H., Gottwald, T. R., Riley, T. D., and Achor, D. 1992. Penetration through leaf stomata and growth of strains of Xanthomonas campestris in citrus cultivars varying in susceptibility to bacterial diseases. Phytopathology 82:1319-1325

Hall, D. G., Gottwald, T. R., and Bock, C. H. 2010. Exacerbation of citrus canker by citrus leafminer, Phyllocnistis citrella in Florida. Fla. Entomol. 93:558-566.

Hodgson, R. W. 1967. Horticultural varieties of citrus. Pages 431-591 in: The Citrus Industry. Volume 1. W. Reuther, H. J. Webber, and L. D. Batchelor eds. Division of Agricultural Sciences, University of California, Berkeley.

Koizumi, M. 1981. Resistance of citrus plants to bacterial canker disease: A review. Proc. Int. Soc. Citricult. 1:402-405.

Koizumi, M., and Kuhara, S. 1982. Evaluation of citrus plants for resistance to bacterial citrus canker disease in relation to the lesion extension. Bull. Fruit Tree Res. Stn. Jpn. D4:73-92.

Laranjeira, F. F., Amorim, L., Bergamin Filho, A., Aguilar-Vildoso, C. I., and Coletta-Filho, H. D. 2005. Fungos, procariotos e doenças abióticas. Pages 509-566 in: Citros. D. Mattos, Jr., J. D. Negri, R. M. Pio, and J. R. Pompeu, eds. Instituto Agronômico e Fundag, Centro APTA Citros Sylvio Moreira, Campinas, São Paulo, Brazil.

Leite, R. P., Jr., and Mohan, S. K. 1984. Evaluation of citrus cultivars for resistance to canker caused by Xanthomonas campestris pv. citri (Hasse) Dye in the State of Paraná, Brazil. Proc. Int. Soc. Citricult. 1:385-389.

Mattos, Jr., D., De Negri, J. D., Pio, R. M., and Pompeu, Jr., J. 2005. Citros, 1 ed. Instituto Agronômico e Fapesp, Campinas, São Paulo, Brazil.

Melotto, M., Underwood, W., and He, S. Y. 2008. Role of stomata in plant innate immunity and foliar bacterial diseases. Annu. Rev. Phytopathol. 46:101-122.

Morton, J. 1987. Orange. Pages 134-142 in: Fruits of Warm Climates. Creative Resource Systems, Inc., Winterville, NC.

Nociti, L. A. S., Camargo, M., Rodrigues Neto, J., Francischini, F. J. B., and Belasque, Jr., J. 2006. Agressividade de linhagens de Xanthomonas axonopodis pv. aurantifolii tipo C em lima ácida Galego. Fitopatol. Bras. 31:140-146.

Pruvost, O., Boher, B., Brocherieux, C., Nicole, M., and Chiroleu, F. 2002 Survival of Xanthomonas axonopodis pv. citri in leaf lesions under tropical environmental conditions and simulated splash dispersal of inoculum. Phytopathology 92:336-346.

Schaad, N. W., Postnikova, E., Lacy, G., Sechler, A., Agarkova, I., Stromberg, V. K., and Vidaver, A. K. 2006. Emended classification of xanthomonad pathogens on citrus. Syst. Appl. Microbiol. 29:690-695.

Schubert, T. S., Rizvi, S. A., Sun, X., Gottwald, T. R., Graham, J. H., and Dixon, W. N. 2001. Meeting the challenge of eradicating citrus canker in Florida-Again. Plant Dis. 85:340-356.

Stall, R. E., Marco, G. M., and de Echenique, B. I. C. 1982. Importance of mesophyll in mature-leaf resistance to cancrosis of citrus. Phytopathology 72 : 1097-1100

Stover, E. W., Richardson, M. L., Driggers, R., Hall, D. G., Duan, Y. P., and Lee, R. F. 2014. Incidence and severity of Asiatic citrus canker on citrus and citrus-related germplasm in a Florida field planting. HortScience 49 4-9.

Vernière, C. J., Gottwald, T. R., and Pruvost, O. 2003. Disease development and symptom expression of Xanthomonas axonopodis pv. citri in various citrus plant tissues. Phytopathology 93:832-843.

Viloria, Z., Drouillard, D. L., Graham, J. H., and Grosser, J. W. 2004. Screening triploid hybrids of Lakeland limequat for resistance to citrus canker. Plant Dis. 88:1056-1060.

Wang, Y., Fu, X. Z., Liu, J. H., and Hong, N. 2011. Differential structure and physiological response to canker challenge between Meiwa kumquat and Newhall navel orange with contrasting resistance. Sci. Hortic. (Amsterdam) 128:115-123.

Zubrzycki, H. M., and Zubrzycki, A. D. 1981. Resistance to Xanthomonas campestris pv. citri (Hasse) Dowson in oranges (Citrus sinensis (L.) Osbeck) Proc. Int. Soc. Citricult. 1:405-409. 